\title{
Distribution of Hydrogen-Producing Bacteria in Tibetan Hot Springs, China
}

OPEN ACCESS

Edited by:

Anna-Louise Reysenbach,

Portland State University,

United States

Reviewed by:

D'Arcy Renee Meyer-Dombard, University of Illinois at Chicago,

United States

Daniel Colman,

Montana State University,

United States

Jeremy Dodsworth,

California State University,

United States

*Correspondence:

Geng Wu

wugeng@cug.edu.cn

Hongchen Jiang

jiangh@cug.edu.cn

Specialty section:

This article was submitted to

Extreme Microbiology,

a section of the journal

Frontiers in Microbiology

Received: 02 June 2020 Accepted: 08 June 2021

Published: 21 July 2021

Citation:

Ma L, Wu G, Yang J, Huang L,

Phurbu D, Li W-J and Jiang H (2021)

Distribution of Hydrogen-Producing

Bacteria in Tibetan Hot Springs,

China. Front. Microbiol. 12:569020.

doi: 10.3389/fmicb.2021.569020

\section{Li Ma ${ }^{1}$, Geng Wu ${ }^{1 *}$, Jian Yang ${ }^{1}$, Liuqin Huang ${ }^{1}$, Dorji Phurbu' ${ }^{2}$, Wen-Jun $L^{3}$ and Hongchen Jiang ${ }^{1 *}$}

${ }^{1}$ State Key Laboratory of Biogeology and Environmental Geology, China University of Geosciences, Wuhan, China, 2 Tibet Plateau Institute of Biology, Lhasa, China, ${ }^{3}$ State Key Laboratory of Biocontrol, Guangdong Key Laboratory of Plant

Resources, School of Life Sciences, Sun Yat-sen University, Guangzhou, China

Investigating the distribution of hydrogen-producing bacteria (HPB) is of great significance to understanding the source of biological hydrogen production in geothermal environments. Here, we explored the compositions of HPB populations in the sediments of hot springs from the Daggyai, Quzhuomu, Quseyongba, and Moluojiang geothermal zones on the Tibetan Plateau, with the use of Illumina MiSeq high-throughput sequencing of $16 \mathrm{~S}$ rRNA genes and hydA genes. In the present study, the hydA genes were successfully amplified from the hot springs with a temperature of $46-87^{\circ} \mathrm{C}$. The hydA gene phylogenetic analysis showed that the top three phyla of the HPB populations were Bacteroidetes (14.48\%), Spirochaetes (14.12\%), and Thermotogae (10.45\%), while Proteobacteria were absent in the top 10 of the HPB populations, although Proteobacteria were dominant in the 16S rRNA gene sequences. Canonical correspondence analysis results indicate that the HPB community structure in the studied Tibetan hot springs was correlated with various environmental factors, such as temperature, $\mathrm{pH}$, and elevation. The HPB community structure also showed a spatial distribution pattern; samples from the same area showed similar community structures. Furthermore, one HPB isolate affiliated with Firmicutes was obtained and demonstrated the capacity of hydrogen production. These results are important for us to understand the distribution and function of HPB in hot springs.

Keywords: Tibet, hot springs, hydrogen-producing bacteria, [FeFe]-hydrogenase, temperature

\section{INTRODUCTION}

Studying microbial distribution and function in geothermal environments is of great significance to the understanding of life evolution and the biogeochemical cycle of elements in high-temperature environments. Geothermal environments are characterized by high temperature, oligotrophic conditions, low dissolved oxygen, and high concentrations of hydrogen gas (Xu and Glansdorff, 2002; Konhauser et al., 2003; Zgonnik, 2020). Hydrogen can serve as one electron donor for microorganisms in geothermal environments (Lindsay et al., 2018; Gregory et al., 2019). The utilization of hydrogen is one of the oldest and most basic properties of life (Kasting, 1993; Lepot, 2020), such that a large quantity of prokaryotes use hydrogen as one energy source (Schwartz and Friedrich, 2006; Fedonkin, 2009). Hydrogen in geothermal environments can be formed through 
geological (abiotic) and biological (biotic) processes (Brazelton et al., 2011; Smetannikov, 2011). The abiotic formation of hydrogen such as the interaction between water and crustal iron minerals has been reported in hydrothermal fluids (Lindsay et al., 2019). However, less attention has been given to the biotic formation of hydrogen in geothermal environments.

In biological processes, fermentative bacteria transform and degrade organic matter and produce metabolic substrates under anaerobic conditions, such as hydrogen, carbon dioxide, and organic acids. Hydrogenase is one key enzyme in the process of microbial hydrogen production. Indeed, about $30 \%$ of microorganisms have genes encoding hydrogenases (Peters et al., 2015). Hydrogenase can be divided into [FeFe]-, [NiFe]-, and [Fe]-hydrogenase according to the metal type of their binding sites (Tard and Pickett, 2009; Lubitz et al., 2014; Greening et al., 2016; Schilter et al., 2016). Generally, [NiFe]-hydrogenase, a type of hydrogen-absorbing enzyme, generally exists in microorganisms that consume hydrogen, but some of them were recently discovered to be present in microorganisms that produce hydrogen; [Fe]-hydrogenase is found only in archaea. In contrast, [FeFe]-hydrogenase catalyzes the reduction of protons to form hydrogen in the presence of electron donors and low oxidation potentials and plays an important role in the formation of hydrogen, but that they may also be reversible, or tied to $\mathrm{H}_{2}$ consumption (e.g., as in electron bifurcation) (Vignais et al., 2001; Vignais and Billoud, 2007; Avilan et al., 2018; Schuchmann et al., 2018). The large subunit of the [FeFe]-hydrogenase is encoded by the hydA gene that is relatively conserved. So, the hydA gene is used for an effective molecular marker to examine the distribution of hydrogen-producing bacteria (HPB) in different environments such as sewage (Tomazetto and Oliveira, 2013), paddy soil (Baba et al., 2014), marine hot springs (Xu et al., 2013), limestone sinkholes (Sahl et al., 2011), terrestrial hot springs (Boyd et al., 2010), anaerobic bioreactor, and salt lakes (Defeng et al., 2008; Boyd et al., 2014). Among these results, hydA genes were mainly affiliated with Thermotogae, Firmicutes, Proteobacteria, and Bacteroidetes. Nevertheless, previous studies were based on cloning and sequencing methods, the depth of information acquisition was insufficient, and they rarely involved the impact of environmental factors (e.g., temperature) on the hydrogen-producing microbial community. As one of the important environmental factors in the geothermal environment (Skirnisdottir et al., 2000; Pearson et al., 2008), temperature also plays an important role in the biological hydrogen production process (Spear et al., 2005; Baghchehsaraee et al., 2008; Zheng et al., 2014). However, little is known about how temperature and other factors affect the diversity of hydrogen-producing microorganisms in geothermal features.

Tibetan hot springs are generally located at an elevation of over 4,000 $\mathrm{m}$ and receive fewer human perturbations, with a wide range of temperature from 22 to $94^{\circ} \mathrm{C}$. Previous studies have investigated the compositions of total microbial communities and some functional microbial groups and their response to environmental variables in Tibetan hot springs (Lau et al., 2006, 2009; Lau and Pointing, 2009; Huang et al., 2011; Song et al., 2013; Wang et al., 2013; Wu et al., 2015; Yang et al., 2015; Zhang et al., 2018; Ma et al., 2021). The purpose of this study was to investigate the diversity of the $\mathrm{HPB}$ and their response to environmental factors in Tibetan hot springs.

\section{MATERIALS AND METHODS}

\section{Sample Collection}

In the present study, hydA gene was successfully amplified in a total of 13 samples from 66 Tibetan hot spring samples (Supplementary Figure 1), including nine samples from two outflowing channels in the Tibetan hot springs (Figure 1). In the Daggyai geothermal zone, the five sampled individual hot springs were labeled with DG01-3, -4, -5, -6, and DG02-2, covering a temperature range of $46-63^{\circ} \mathrm{C}$; In the Quzhuomu geothermal zone, the collected samples along the outflowing channels of hot springs were labeled with QZM04, 04-1, -2, -3, -and -4, covering a temperature range of $54-72^{\circ} \mathrm{C}$. In addition, three sample hot springs were selected in the Moluojiang geothermal area and the Quseyongba geothermal area and were labeled with MLJ-05 $\left(87^{\circ} \mathrm{C}\right)$, QSYB09-3 $\left(70^{\circ} \mathrm{C}\right)$, and QSYB09-4 $\left(66^{\circ} \mathrm{C}\right)$, respectively. At each sampling site, water temperature and $\mathrm{pH}$ were measured in situ with a temperature/pH probe (LaMotte, Chestertown, MD, United States). Water chemistry parameters, such as oxidationreduction potential index (Eh), electrical conductivity (EC), and total dissolved solids (TDS), were measured in situ by using portable water quality analyzer (Thermo Scientific ORION STAR A329, Beverly, MA, United States). For dissolved organic carbon (DOC) analysis, $25 \mathrm{ml}$ of hot spring water was collected by a sterile $50-\mathrm{ml}$ syringe and filtered through pre-combusted $\left(450^{\circ} \mathrm{C}, 4 \mathrm{~h}\right) \mathrm{GF} / \mathrm{F}$ filters $(0.7-\mathrm{mm}$ pore size, Whatman, Buckinghamshire, United Kingdom), and the resulting filtrate was collected into pre-combusted brown glass bottles with the addition of concentrated phosphoric acid [final concentration $0.2 \%(\mathrm{v} / \mathrm{v})]$. Hot spring water $(25 \mathrm{ml})$ was filtered through $0.22-\mathrm{m}$ nitrocellulose membranes and collected into acid-washed polyethylene bottles for major anion measurement; $25 \mathrm{ml}$ of hot spring water was filtered through polycarbonate membrane filters (pore size $0.22 \mathrm{~mm}$ ) and collected into glass bottles supplemented with concentrated $\mathrm{HNO}_{3}$ (to a final concentration of $0.1 \mathrm{M}$ ) for major cation measurement. Sediments for microbial analyses were collected in 50-ml Falcon tubes and were then frozen in dry ice in the field and during transportation. Once in the laboratory, the sediment samples were stored at $-80^{\circ} \mathrm{C}$ until further analysis.

\section{Geochemical Analyses}

Major anion concentrations of the collected hot spring water samples were measured using an ion chromatograph (IonPac AS18 $4 \times 250 \mathrm{~mm}$ for anion, ICS 600, Thermo Fisher, Carlsbad, USA). The standard stock solutions $\left(100 \mu \mathrm{g} \mathrm{ml}^{-1}\right)$ of multi-ion anion standards including fluoride $\left(\mathrm{F}^{-}\right)$, chloride $\left(\mathrm{Cl}^{-}\right)$, nitrate $\left(\mathrm{NO}_{3}{ }^{-}\right)$, and sulfate $\left(\mathrm{SO}_{4}{ }^{2-}\right)$ were purchased from General Research Institute for Non-ferrous Metals (No. GSB04-33692016, Beijing, China). Column temperature was maintained at $30^{\circ} \mathrm{C}$, the flow rate was $1 \mathrm{ml} / \mathrm{min}$, and eluent liquid was $31 \mathrm{mM}$ $\mathrm{NaOH}$. The DOC contents were measured by using an $\mathrm{NC}$ 2100 Elemental Analyzer (multi N/C 2100, Analytic Jena, Jena, Überlingen, Germany). The concentrations of $\mathrm{Ca}, \mathrm{K}, \mathrm{Mg}, \mathrm{Na}$, 


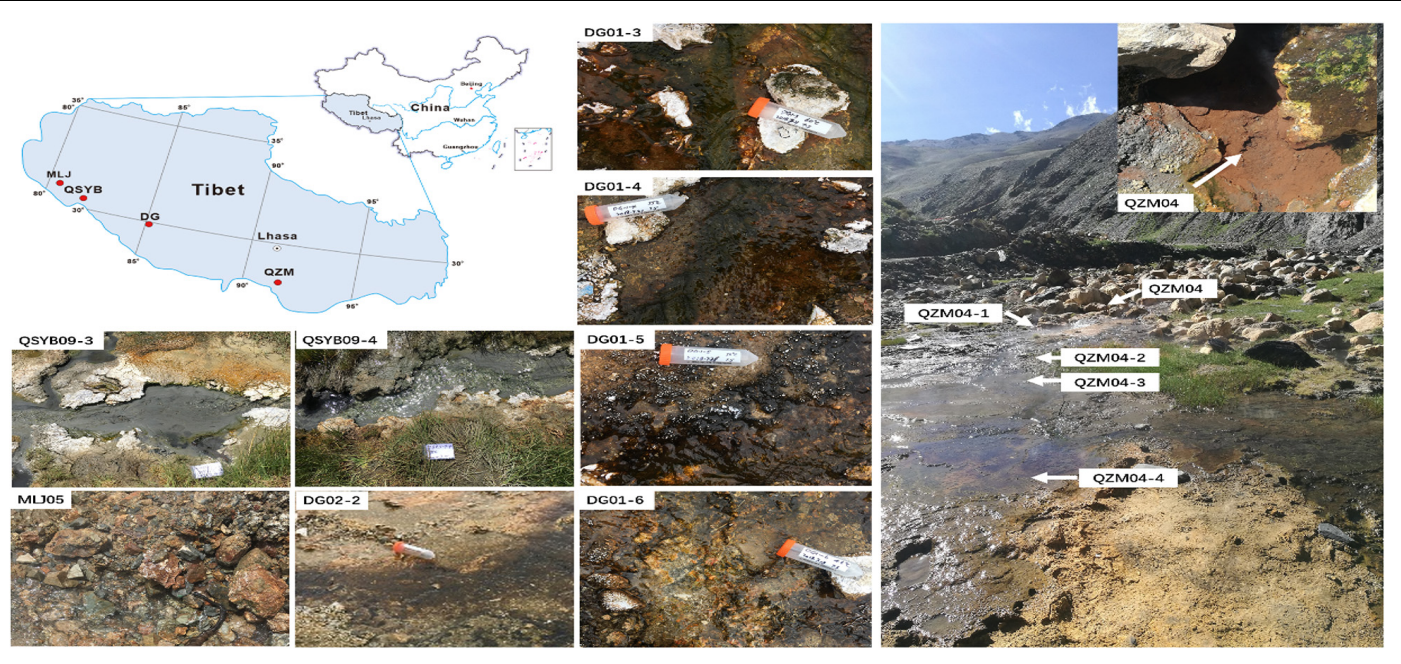

FIGURE 1 | The locations of the studied geothermal zones in the Tibetan Plateau. QSYB, Quseyongba; MLJ, Moluojiang; DG, Daggyai; and QZM, Quzhuomu.

and Fe were determined by ICP-OES (Thermo Fisher ICAP6300, Carlsbad, United States). The standard stock solutions $\left(1 \mu \mathrm{g} \mathrm{ml}^{-1}\right)$ of multi-element standards including sodium (Na), potassium $(\mathrm{K})$, calcium $(\mathrm{Ca})$, and magnesium $(\mathrm{Mg})$ stored in $5 \% \mathrm{HNO}_{3}$ were purchased from General Research Institute for Non-ferrous Metals (No. GNM-M275017-2013, Beijing, China).

\section{DNA Extraction, PCR Amplification, and Sequencing}

Total community DNA of the collected hot spring sediments were extracted with FastDNA Spin Kit according to the manufacturer's instructions (MP Biomedicals, LLC, Solon, $\mathrm{OH}$ ). Bacterial and Archaeal 16S rRNA genes were amplified with a universal primer set of 515F (5'GTGYCAGCMGCCGCGGTA$\left.3^{\prime}\right) / 806 \mathrm{R}$ (5'-GGACTACVSGGGTATCTAAT-3') according to the PCR conditions described previously (Tamaki et al., 2011; Caporaso et al., 2012; Zhang et al., 2018). The hydA genes of the total community DNA in the collected hot spring sediments were PCR amplified using the primer set FeFe-272F (5'-GCHGAYMTBACHATWATGGARGA-3', where $\mathrm{H}=\mathrm{A}, \mathrm{C}, \mathrm{T} ; \mathrm{Y}=\mathrm{C}, \mathrm{T} ; \mathrm{M}=\mathrm{A}, \mathrm{C} ; \mathrm{B}=\mathrm{C}, \mathrm{G}, \mathrm{T}$; $\mathrm{W}=\mathrm{A}, \mathrm{T} ; \mathrm{R}=\mathrm{A}, \mathrm{G} ; 432$-fold degeneracy) $/ \mathrm{FeFe}-427 \mathrm{R}$ (5'-GCNGCYTCCATDACDCCDCCNGT-3', where $\mathrm{N}=\mathrm{A}, \mathrm{C}$, $\mathrm{T}, \mathrm{G} ; \mathrm{Y}=\mathrm{C}, \mathrm{T} ; \mathrm{D}=\mathrm{A}, \mathrm{G}, \mathrm{T} ;$ 864-fold degeneracy) (Boyd et al., 2010; Sahl et al., 2011; Baba et al., 2014). A unique 12bp barcode sequence is added between the sequencing adapter and the forward primer to distinguish among samples. PCR conditions of hydA genes were as follows: initial denaturation at $94^{\circ} \mathrm{C}(4 \mathrm{~min})$, and 35 cycles of denaturation at $94^{\circ} \mathrm{C}(1 \mathrm{~min})$, annealing at $56.5^{\circ} \mathrm{C}(1 \mathrm{~min})$, and extension at $72^{\circ} \mathrm{C}(1 \mathrm{~min})$, followed by a final extension at $72^{\circ} \mathrm{C}(20 \mathrm{~min})$ (Boyd et al., $2009,2010,2014)$. In order to ensure the reliability of the results, triplicate PCRs and experimental blanks were conducted for each sample. Then, the successful 16S rRNA gene and hydA gene PCR products were purified with the AxyPrep DNA Gel Extraction Kit (Axygen Scientific Inc., Union City, CA, United States) and sequenced by using an Illumina-Hiseq2500 platform $(2 \times 250 \mathrm{bp})$ and Illumina-MiSeq platform $(2 \times 300 \mathrm{bp})$, respectively.

\section{Processing of the 16S rRNA Gene and hydA Gene Illumina Sequencing Data}

The obtained paired-end raw reads were quality filtered with Trimmomatic (V0.33) ${ }^{1}$. Reads having the following properties were removed: (1) receiving a quality score $<20$; (2) containing one or more ambiguous base calls; and (3) comprising consecutive high-quality base calls $<75 \%$ of the total read coverage length. The resulting high-quality paired-end reads were assembled with FLASH (V1.2.11, fast length adjustment of short reads) using default settings (Magoc and Salzberg, 2011). Sequences were assigned to each sample based on their unique barcodes, and then the barcodes and primers were removed. The effective sequences were clustered into operational taxonomic units (OTUs) at the cutoff of $97 \%$ similarity by using the USEARCH software, and chimeric sequences and singleton OTU sequences were excluded to avoid possible biases (Edgar et al., 2011). Phylogenetic information was assigned for the obtained representative OTU sequences by using the SILVA database v132 (for 16S rRNA) ${ }^{2}$ and Non-Redundant Protein Sequence Database (for $h y d A)^{3}$ with the confidence threshold $\geq 0.5$ by default. The OTU table was rarefied to an equal sequence number for each sample, and then the resulting rarefied OTU table was employed in subsequent analyses unless specified otherwise.

\section{Statistical Analysis}

We standardized the measured environmental factor data and applied it together with the hydA OTU table for the subsequent statistical analysis (Table 1). Statistical analysis was performed

\footnotetext{
${ }^{1}$ http://www.usadellab.org/cms/?page=trimmomatic

${ }^{2}$ https://www.arb-silva.de/

${ }^{3}$ https://ftp.ncbi.nlm.nih.gov/blast/db/FASTA/
} 
by using various packages in the $\mathrm{R}$ program $^{4}$ (version $\mathrm{R}$ 3.5.2, 2018-12) unless stated otherwise. Alpha diversity indices were calculated by using $\mathrm{R}$ package "vegan." Linear regression analysis was employed to assess the correlation between the observed OTUs and measured environmental factors of the studied samples by using the PAST software. Relative abundance histogram was constructed to assess differences in population abundance in samples from different regions by using package "reshape2," and Pearson's rank correlations were calculated between the measured environmental variables and population relative abundance by using the package "Hmisc." The autocorrelation test of environmental factors was carried out by using the package "Hmisc." The analyzed geochemical parameters were assessed for the variable inflation factor (VIF) using the Vegan package of $\mathrm{R}$ Project to reduce the number of highly co-linear variables. The VIF assessment was repeated until all the remaining environmental variables exhibited maximum VIF values of no higher than 10. After removing the autocorrelation factor, canonical correspondence analysis (CCA) was applied to evaluate the impact of remaining environmental factors and spatial variables on the HPB community structures by using "vegan" and "ggplot2" packages. A spatial decomposition method, principal coordinates of neighbor matrices (PCNM), was applied to the geographic coordinates of the samples. This method separates sample geographic coordinates into multiple spatial variables. Then, the significant $(p<0.05)$ spatial variables were selected for variation partitioning analysis (VPA). VPA was performed to determine the relative contributions of the measured environmental variables (environmental factors after removing autocorrelation) and spatial variables to the distribution of HPB community structures using the "vegan" package. The residual proportion represented unexplained variance.

\section{Cultivation and Isolation of HPB}

The hot spring sediments of QZM04-4 with positive hydA gene amplification were chosen for HPB isolation. Previous studies showed that hydrogen production is the most effective after heat treatment at $55^{\circ} \mathrm{C}$ (Zheng et al., 2014), which covered the samples in the main temperature range of our study. So, the QZM044 hot spring sediment was selected for HPB isolation. One milliliter of sediment slurry (hot spring sediment:water $=1: 30$, $\mathrm{v}: \mathrm{v})$ was inoculated into pre-reduced PY broth in glove box (Holdeman et al., 1977). The basal medium used for cultivation of HPB contained the following (per liter): $0.5 \mathrm{~g}$ of $\mathrm{KH}_{2} \mathrm{PO}_{4}$, $1.2 \mathrm{~g}$ of $\mathrm{Na}_{2} \mathrm{HPO}_{4}, 0.29 \mathrm{~g}$ of $\mathrm{NH}_{4} \mathrm{Cl}, 0.29 \mathrm{~g}$ of $\mathrm{NaCl}, 0.001 \mathrm{~g}$ of $\mathrm{CaCl}_{2} \cdot 2 \mathrm{H}_{2} \mathrm{O}, 0.01 \mathrm{~g}$ of $\mathrm{MgCl}_{2} \cdot 6 \mathrm{H}_{2} \mathrm{O}, 1 \mathrm{~g}$ of yeast extract, $0.05 \mathrm{~g}$ of cysteine- $\mathrm{HCl}, 1 \mathrm{ml}$ of $0.1 \%$ resazurin solution, and $10 \mathrm{ml}$ of trace mineral element solution (Mei et al., 2014). After sterilization, glucose was added as substrate in concentration $(2 \mathrm{~g} / \mathrm{L}$, final concentration), and $\mathrm{NaHCO}_{3}(3.92 \mathrm{~g} / \mathrm{L}$, final concentration) and $\mathrm{Na}_{2} \mathrm{~S} \cdot 9 \mathrm{H}_{2} \mathrm{O}(0.02 \mathrm{~g} / \mathrm{L}$, final concentration) were added as reducing agents. Then, the cultures were cultivated at $55^{\circ} \mathrm{C}$ for $24 \mathrm{~h}$. Subsequently, the resulting enrichments were used for isolation with the use of Hungate roll-tube technique (Hungate,

${ }^{4}$ http://cran.r-project.org/
1969). Single colonies were selected and transferred to the same broth, followed by incubation at $55^{\circ} \mathrm{C}$ for 3 days. The cultures were added with $0.2 \% \mathrm{BrES}$ to inhibit the growth of methanogens. The above isolation procedures were repeated several times until pure cultures were obtained.

\section{DNA Isolation, PCR Amplification, and Phylogenetic Analyses of Isolates}

Genomic DNA of the obtained bacterial isolates was extracted with FastDNA Spin Kit (MP Biomedicals, LLC, Solon, OH). The 16S rRNA and hydA genes of the obtained isolates were PCR amplified using the primer sets of 27F/1492R (Frank et al., 2008) and $\mathrm{FeFe}-272 \mathrm{~F} / \mathrm{FeFe}-427 \mathrm{R}$, respectively. PCR conditions of $16 \mathrm{~S}$ rRNA genes were as follows: initial denaturation at $95^{\circ} \mathrm{C}$ (5 min), and 35 cycles of denaturation at $94^{\circ} \mathrm{C}(30 \mathrm{~s})$, annealing at $52^{\circ} \mathrm{C}(30 \mathrm{~s})$, and extension at $72^{\circ} \mathrm{C}(1.5 \mathrm{~min})$, followed by a final extension at $72^{\circ} \mathrm{C}(10 \mathrm{~min})$. PCR conditions of hydA genes were the same as those of the sediment samples. The resulting successful 16S rRNA and hydA gene PCR products were purified with the AxyPrep DNA Gel Extraction Kit. The purified $16 \mathrm{~S}$ rRNA and hydA gene PCR products of strain QZM-1 were sequenced with Sanger sequencing. The obtained sequences were aligned in GenBank database (version 242). Maximum likelihood phylogenetic trees of the $16 \mathrm{~S}$ rRNA sequence and hydA amino acid sequence of the obtained bacterial isolates were constructed with the Poisson model in MEGA 7.0 (Saitou and Nei, 1987) and bootstrap replicates 1,000 times.

\section{Hydrogen Production Test of Hydrogen-Generating Cultures}

The $\mathrm{H}_{2}$ production tests were performed under batch conditions in 120-ml serum bottles capped with rubber stoppers. Three milliliters of the early-stationary-phase pre-culture on PY medium (containing $2 \mathrm{~g} / \mathrm{L}$ of glucose) was transferred anaerobically in $30 \mathrm{ml}$ of the basal culture medium as inoculum. Prior to inoculation, the upper air and lower medium liquid go through $\mathrm{N}_{2}$-flushing and sterilization. The experiment was carried out at $55^{\circ} \mathrm{C}$ and assays were performed at least in triplicate. One milliliter of the headspace was regularly $(4,8,12$, 24,48 , and $96 \mathrm{~h}$ ) collected for measuring $\mathrm{H}_{2}$ content with the use of one Agilent 7890A gas chromatograph with a TCD detector, the column model was C38743-14, carrier gas was nitrogen at a pressure of $100 \mathrm{kPa}$, and running time was $2 \mathrm{~min}$.

\section{Nucleotide Sequence Accession Numbers}

The 16S rRNA high-throughput sequences generated in this study were deposited in the NCBI SRA database under the BioProject ID PRJNA638734 with accession number SRR12042849-SRR12042861. The hydA high-throughput sequences generated in this study were deposited in the NCBI SRA database under the BioProject ID PRJNA 693970 with accession number SRR13505064-SRR13505076. 


\section{RESULTS}

\section{Geochemical Characteristics of the Studied Hot Springs}

Geochemical characteristics of the studied hot springs are diverse (Table 1). Briefly, the elevation of the studied hot spring ranged from $4,620 \mathrm{~m}$ above sea level (masl) to 5,057 masl; the temperature of the studied hot springs ranged from 46 to $87^{\circ} \mathrm{C}$. The hot springs in the Quzhuomu geothermal zone possessed lower $\mathrm{pH}(6.8-7.6)$ than those in the other geothermal zone (8.55-8.96), while Eh index (-0.3 to -42.5$)$ was higher than other geothermal zones ( -94.8 to -278.8$)$. The values of EC and TDS in the Moluojiang geothermal zone were the highest, while those in other areas were more consistent (Table 1). In addition, hot springs from the Quzhuomu geothermal zone had higher concentrations of $\mathrm{Ca}^{2+}\left(163.7-173.0 \mathrm{mg} \mathrm{L}^{-1}\right.$ vs. 0.97-2.02 $\mathrm{mg} \mathrm{L}^{-1}$ ) and $\mathrm{SO}_{4}{ }^{2-}\left(491.2-513.7 \mathrm{mg} \mathrm{L}^{-1}\right.$ vs. 87.17$90.18 \mathrm{mg} \mathrm{L}^{-1}$ ) than those from the DG geothermal zones, while the concentration of $\mathrm{Na}^{+}\left(297.6-315.4 \mathrm{mg} \mathrm{L}^{-1}\right.$ vs. 166.8$172.2 \mathrm{mg} \mathrm{L}^{-1}$ ) in the DG area was higher than that in the Quzhuomu area. From the results of the $\mathrm{Cl}^{-} / \mathrm{SO}_{4}{ }^{2-}$ ratio, the concentration of $\mathrm{Cl}^{-}$was higher than that of $\mathrm{SO}_{4}{ }^{2-}$ in the MLJ, QSYB, and DG geothermal areas, while the results of the QZM geothermal area were just the opposite. This suggested that only the QZM hot spring was mainly influenced by vapor phase, while hot springs in other areas were mainly influenced by liquid phase.

\section{$16 S$ rRNA and hydA Gene Diversity of the Studied Hot Springs}

Phylogenetic analysis showed that these 16S rRNA gene OTUs were mainly affiliated with the 10 most dominant phyla, i.e., Chloroflexi (25.30\%), Proteobacteria (13.15\%), Bacteroidetes (10.00\%), Cyanobacteria (8.23\%), Acetothermia (5.65\%), Firmicutes (5.08\%), Deinococcus-Thermus (4.13\%), Acidobacteria (3.90\%), Nanoarchaeaeota (3.01\%), and Nitrospirae (2.77\%), as well as others (18.77\%), in a decreasing order (Figure 2A). A total of 771,199 high-quality hydA gene sequences were obtained from all the studied hot spring samples $(n=13)$, with an average of 59,323 sequences per sample. These sequences were classified into 3331 OTUs (Supplementary Table 1). The observed OTUs were significantly $(p<0.05)$ negatively correlated with Eh and elevation (Figure 3). Phylogenetic analysis showed that these hydA gene OTUs were mainly affiliated with the 10 most dominant phyla, i.e., Bacteroidetes (14.48\%), Spirochaetes (14.12\%), Thermotogae (10.45\%), Chlorobi (7.66\%), Firmicutes (6.93\%), Armatimonadetes (4.51\%), Planctomycetes (2.45\%), Acidobacteria (1.63\%), Hydrogenedentes $(0.75 \%)$, and Elusimicrobia (0.68\%), as well as others (36.34\%), in a decreasing order (Figure 2B).

The hydA genes affiliated with Bacteroidetes and Spirobacteria dominated the studied samples regardless of their temperature or regions, but the abundances of other phyla were different. For example, the hydA gene sequences affiliated with Firmicutes in the DG region showed much higher abundance than that in the QZM region ( $8 \%$ vs. $1.72 \%$ ), while those affiliated with Chlorobi showed an opposite trend between these two regions $(4.16 \%$ vs. $15.16 \%)$. In addition, the samples of different temperature ranges were also different. For example, in the samples with temperature higher than $70^{\circ} \mathrm{C}$, the top three most abundant phyla of hydA genes were Bacteroidetes, Spirochaetes, and Armatimonadetes; those in the samples with temperature $60-70^{\circ} \mathrm{C}$ were Bacteroidetes, Spirochaetes, and Thermotogae; and those in the samples with temperature below $60^{\circ} \mathrm{C}$ were Bacteroidetes, Spirochaetes, and Chlorobi (Figure 2B). Pearson's rank correlation analysis showed that the relative abundance of hydA genes affiliated with Firmicutes was significantly positively correlated with $\mathrm{pH}(p<0.05)$, while it was significantly negatively correlated with Eh $(p<0.05)$. In addition, the relative abundance of hydA genes affiliated with Armatimonadetes, Acidobacteria, and Elusimicrobia showed significantly negative correlation with $\mathrm{pH}(p<0.05)$ (Supplementary Figure 2).

\section{Statistical Analysis}

Autocorrelation test among the measured environmental factors showed that temperature was significantly $(p<0.05)$ positively correlated with the electrical conductivity and

TABLE 1 | Geographical and geochemical parameters of the investigated hot springs in this study.

\begin{tabular}{|c|c|c|c|c|c|c|c|c|c|c|c|}
\hline Sites & Characteristics & Samples & GPS location (N/E) & Elevation (m) & $\mathrm{pH}$ & Temp $\left({ }^{\circ} \mathrm{C}\right)$ & Eh (mv) & DOC (mg/L) & $\mathrm{EC}(\mu \mathrm{s} / \mathrm{cm})$ & TDS (mg/L) & $\mathrm{Fe}$ \\
\hline \multirow[t]{2}{*}{ Quseyongba (QSYB) } & Channel springs & QSYB09-3 & $81.5806^{\circ} / 30.5848^{\circ}$ & 4,620 & 8.9 & 70 & -278.8 & 28.38 & 1,828 & 896.3 & 2.13 \\
\hline & & QSYB09-4 & $81.5806^{\circ} / 30.5848^{\circ}$ & 4,620 & 8.96 & 66 & -274.1 & 12.11 & 1,804 & 884.2 & 1.84 \\
\hline Moluojiang (MLJ) & Individual spring & MLJ-05 & $80.4914^{\circ} / 31.3690^{\circ}$ & 4,863 & 8.48 & 87 & -94.8 & 1.86 & 5,447 & 2670 & 1.16 \\
\hline \multirow[t]{5}{*}{ Daggyai (DG) } & Channel springs & DG01-3 & $85.7509^{\circ} / 29.5982^{\circ}$ & 5,057 & 8.7 & 60 & -102.9 & 21.86 & 1,834 & 899.3 & 0.86 \\
\hline & & DG01-4 & $85.7509^{\circ} / 29.5982^{\circ}$ & 5,057 & 8.71 & 55 & -104.7 & 8.05 & 1,855 & 909.6 & 0.96 \\
\hline & & DG01-5 & $85.7509^{\circ} / 29.5982^{\circ}$ & 5,057 & 8.75 & 50 & -106.4 & 18.81 & 1,840 & 902.3 & 1.11 \\
\hline & & DG01-6 & $85.7509^{\circ} / 29.5982^{\circ}$ & 5,057 & 8.6 & 46 & -101.9 & 23.45 & 1,835 & 899.8 & 0.92 \\
\hline & Individual spring & DG02-2 & $85.7507^{\circ} / 29.5988^{\circ}$ & 5,058 & 8.55 & 63 & -102.6 & 8.03 & 1,842 & 903.1 & 0.92 \\
\hline \multirow[t]{5}{*}{ Quzhuomu (QZM) } & Channel springs & QZM04 & $91.8127^{\circ} / 28.2367^{\circ}$ & 4,853 & 6.87 & 72 & -0.3 & 18.26 & 2,037 & 998.4 & 2.38 \\
\hline & & QZM04-1 & $91.8127^{\circ} / 28.2367^{\circ}$ & 4,853 & 7.17 & 67 & -18.0 & 18.27 & 2,057 & 1,025 & 1.88 \\
\hline & & QZM04-2 & $91.8127^{\circ} / 28.2367^{\circ}$ & 4,853 & 6.98 & 62 & -6.3 & 21.01 & 2,085 & 1,022 & 2.09 \\
\hline & & QZM04-3 & $91.8127^{\circ} / 28.2367^{\circ}$ & 4,853 & 7.29 & 58 & -24.7 & 21.8 & 2,082 & 1,021 & 1.79 \\
\hline & & QZMO4-4 & $91.8127^{\circ} / 28.2367^{\circ}$ & 4,853 & 7.6 & 54 & -42.5 & 11.82 & 2,054 & 1,007 & 1.37 \\
\hline
\end{tabular}



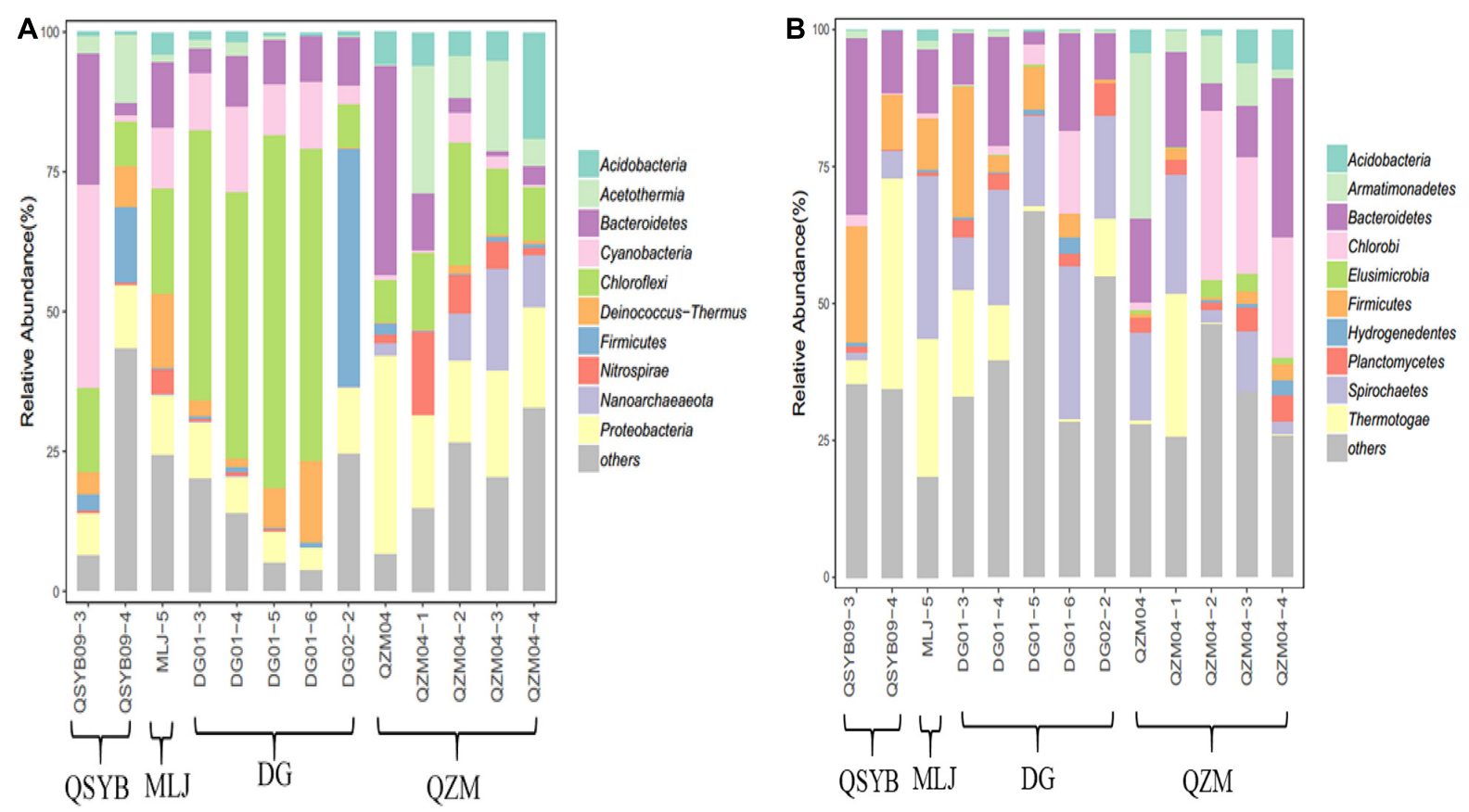

FIGURE 2 | Phylogenetic analysis of the obtained 16S rRNA (A) and hydA gene (B) sequences of the studied hot spring samples.

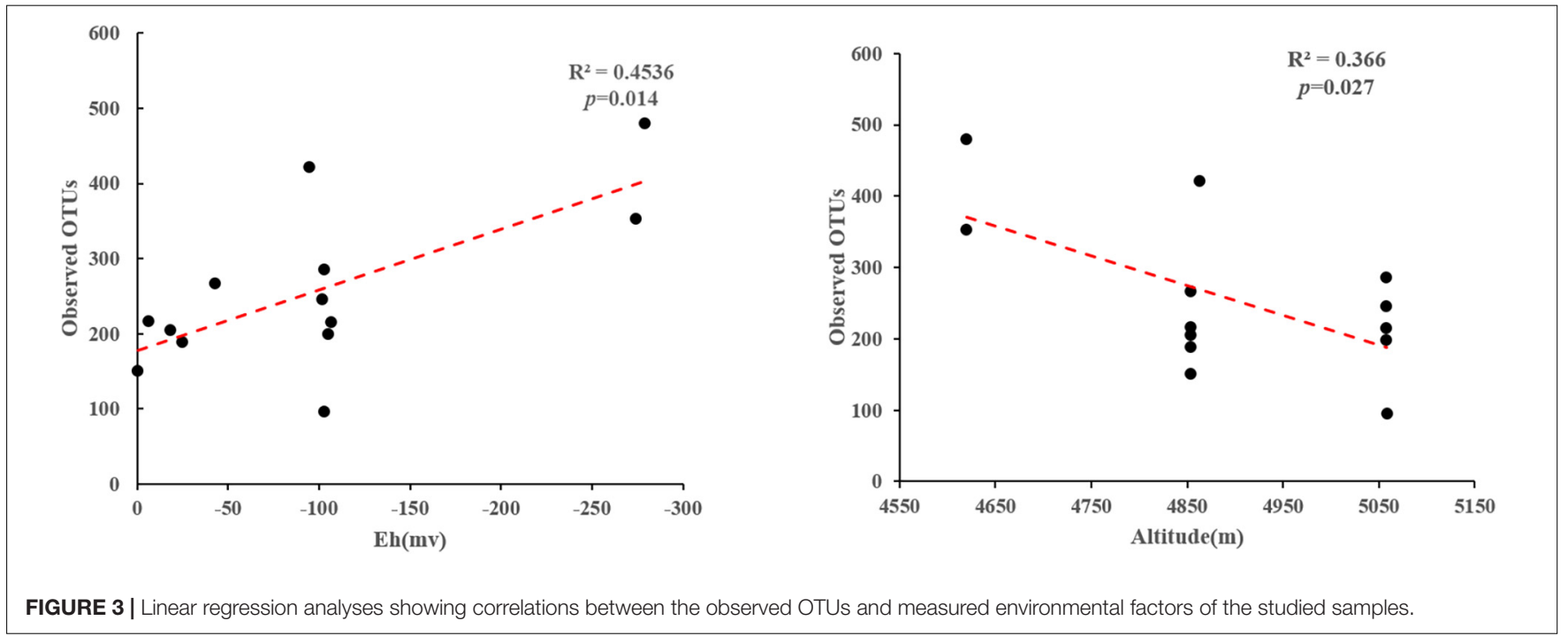

total dissolved solids, while the $\mathrm{pH}$ of the studied samples showed negative correlation with the Eh (Supplementary Figure 3). Among all the measured environmental factors, the CCA results showed that the HPB community structure was correlated with elevation, temperature, $\mathrm{pH}$, and spatial factors (PCNM1 and PCNM3) (Figure 4). The VPA results showed that the measured environmental factors (e.g., elevation, $\mathrm{pH}$, and temperature) and spatial variables can totally explain $39 \%$ of the observed variations of the HPB community structure in the studied hot springs. These two types of factors (i.e., environmental vs. spatial) co-explained $25 \%$ variations, while they accounted for $33 \%$ and $31 \%$ of the observed variations of the HPB community structure, respectively (Figure 5).

\section{Phylogenetic Analysis and Hydrogen Production of Strain QZM-1}

One strictly anaerobic hydrogen-producing bacterium was isolated from the sediments of Quzhuomu hot spring and was named QZM-1. The full length of the 16S rDNA sequence of strain QZM-1 was 1,424 bp. Phylogenetic analysis showed that QZM-1 is closely related to Thermobrachium celere and Caloramator coolhaasii, with 16S rRNA gene similarity of $98.38 \%$ 


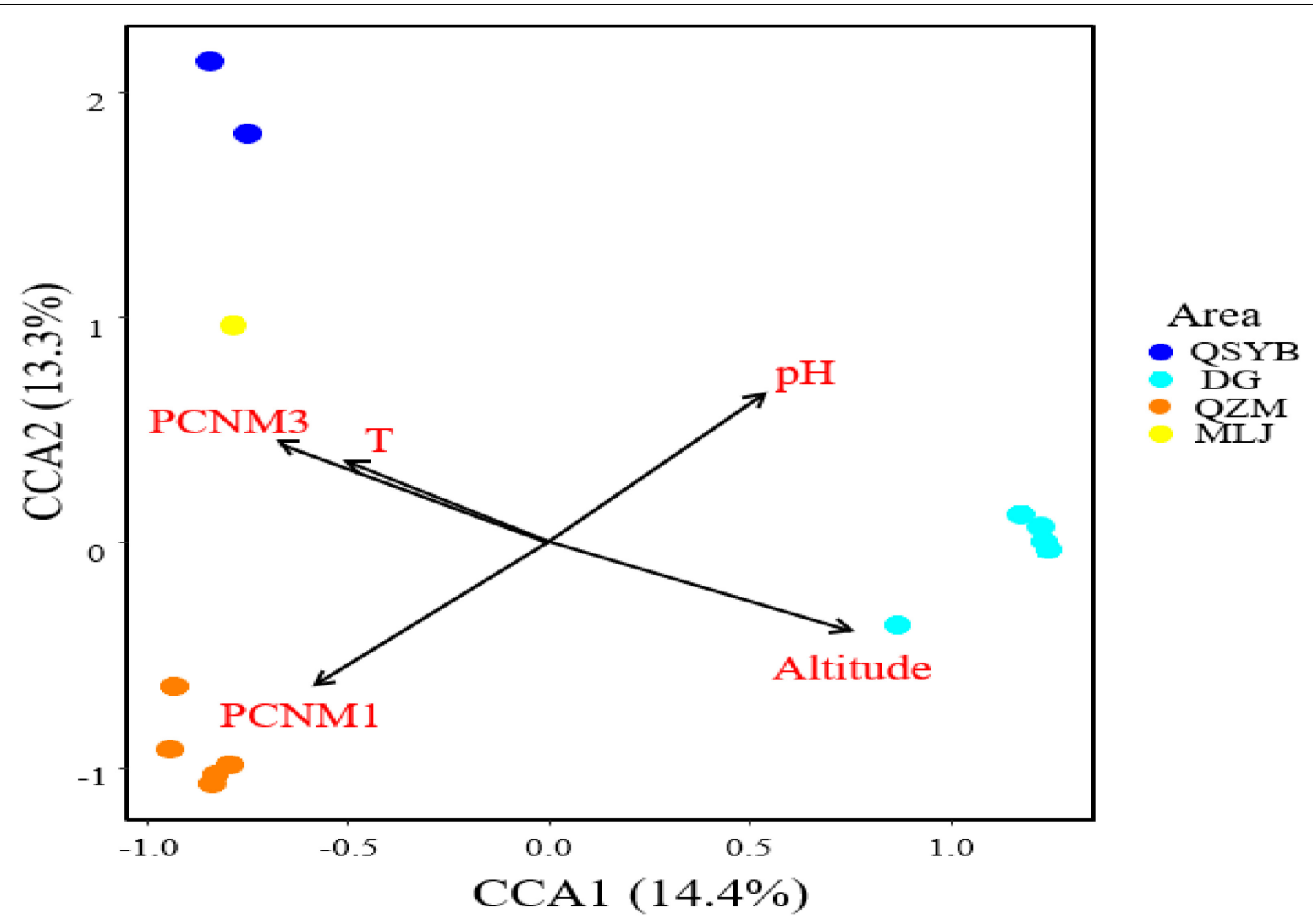

FIGURE 4 | CCA analysis showing the influence of environmental factors and geographic factors on the hydrogen-producing bacteria community structures. Assemblages sampled from the QZM, DG, DG01 (DG02-2), QSYB, and MLJ area are denoted in orange, sky blue, green, dark blue, and yellow, respectively.

and $97.47 \%$, respectively. The hydA gene sequence of strain QZM-1 showed $98.58 \%$ similarity with $T$. celere. Therefore, the phylogenetic analysis suggested that strain QZM-1 likely belonged to the genus Caloramator rather than Thermobrachium (Supplementary Figures 4A,B). Our high-throughput data showed that the sequence reads belonging to the Caloramator genus accounted for 0.5 and $0.37 \%$ of the total $16 \mathrm{~S}$ rRNA and hydA genes, respectively. Strain QZM-1 showed the capacity of producing hydrogen in the fermentation experiments (Supplementary Figure 5). Hydrogen production occurred at the time of the first sampling point. After the logarithmic growth phase, the hydrogen production gradually stabilized and reached the maximum value of $3.32 \% \mathrm{H}_{2}$ at $96 \mathrm{~h}$ (Supplementary Figure 5). The GenBank accession numbers of 16S rRNA and hydA genes of strain QZM-1 were MW517843 and MW514309, respectively.

\section{DISCUSSION}

\section{HPB Diversity in the Tibetan Hot Springs}

In this study, the HPB populations in the Tibetan hot spring samples were mainly composed of species affiliated with Bacteroidetes and Spirochaetales, similar to the dominant species in neutral high-temperature oil wells (Liu et al., 2016), but different from the dominant species in acidic hot springs in Yellowstone National Park (YNP) (Boyd et al., 2010). Proteobacteria-related HPB have been repeatedly found to be the main group in acidic and neutral environments. It is worth noting that Proteobacteria accounted for $13.15 \%$ of the total $16 \mathrm{~S}$ rRNA gene sequences in the studied samples, but Proteobacteria-related HPB only accounted for $0.06 \%$ of the total hydA gene sequences. However, they were dominant in acidic and neutral environments (Boyd et al., 2010; Schmidt et al., 2010; Tomazetto and Oliveira, 2013). Such inconsistency could be ascribed to the different environmental conditions between the Tibetan hot springs and those referred hot springs or high-temperature habitats. For example, the abovementioned oil reservoir environment had similar temperature and $\mathrm{pH}$ conditions to the hot spring samples in this study, while the temperature of the referred YNP hot springs was mostly below $50^{\circ} \mathrm{C}$ and that of other acidic and neutral environments was generally below $30^{\circ} \mathrm{C}$. Moreover, previous studies have found that $\mathrm{pH}$ is a key factor affecting the HPB diversity (Boyd et al., 2010; Schmidt et al., 2010). Therefore, it is reasonable to observe the difference of the HPB populations between the studied Tibetan hot springs and other environments.

By combining the phylogenetic analysis results of $16 \mathrm{~S}$ rRNA genes, Spirochaetales, Thermotogae, and Chlorobi were all the main groups containing hydA gene in the studied samples, but 


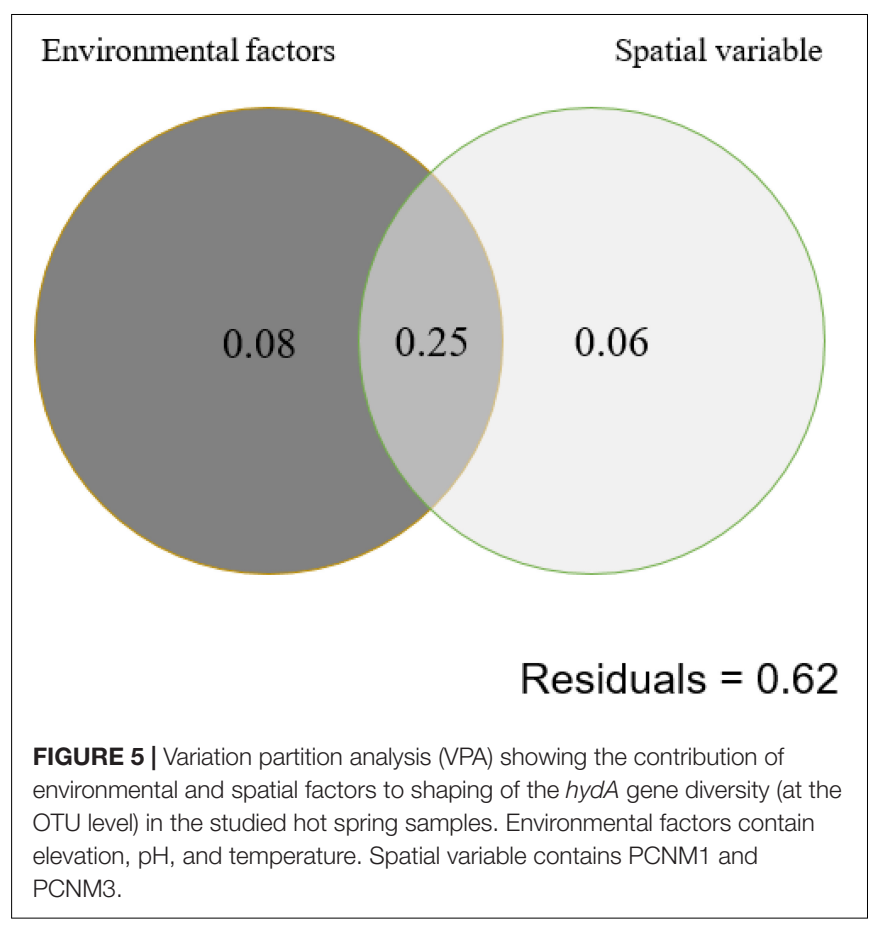

it appeared that all of these three groups occupied extremely low abundance. This finding implied that some rare populations in the environment may contribute more to the element cycle of the entire ecosystem. When we explore the relationship between microorganisms and environments, rare taxa cannot be ignored (Zhang et al., 2018).

\section{Environmental Factors Influencing HPB Population in the Tibetan Hot Springs}

Temperature is one of the important environmental factors affecting hot spring microorganisms (Wang et al., 2013; Guo et al., 2020). For HPB, temperature is an important factor affecting the hydrogen production process (Guo et al., 2010; Ghimire et al., 2015). It has been shown that the hydA gene has not been found in the samples above $65^{\circ} \mathrm{C}$ in the YNP hot springs (Boyd et al., 2010). Interestingly, we successfully amplified the hydA gene in one hot spring with $87^{\circ} \mathrm{C}$ and in other four hot springs with temperatures $>65^{\circ}$, which deserved further study (Supplementary Figure 1). In general, the hydA gene was found more frequently in Tibetan hot springs with a temperature of $50-70^{\circ} \mathrm{C}$; this also implies the suitable temperature range of microbial hydrogen production in the hot spring environment. In the studied samples, the abundances of hydA genes affiliated with HPB dominant groups were also different in different temperature ranges. Interestingly, in the samples with temperature above $60^{\circ} \mathrm{C}$, the hydA gene affiliated with Thermotogae was more abundant than that belonging to Chlorobi, but in the samples with temperature below $60^{\circ} \mathrm{C}$, the trend was opposite. This situation also happened in the samples from the same area. For example, in the samples of DG01-3 and DG02-2 in the DG region, the abundance of hydA gene affiliated with Thermotogae was higher than that of the other three samples, while that affiliated with Chlorobi showed an opposite trend. The similar situation was also found in the QZM area (Figure 2B). Therefore, such difference could be explained by the fact that different types of strains had different adaptation temperatures. Thermotogae were characteristic of thermophilicity, and Chlorobi were a type of photosynthetic autotrophic bacteria that can grow in a lower temperature range (Iino et al., 2010; Bhandari and Gupta, 2014). Such a trend was not found in the $16 \mathrm{~S}$ rRNA gene results, suggesting that temperature may specifically affect microorganisms containing the hydA gene. Therefore, it is reasonable to observe from the CCA results that temperature was related with the HPB community structure in Tibetan hot springs.

$\mathrm{pH}$ was also one key factor affecting the population structure of HPB (Figure 4), which was consistent with previous research results. The $\mathrm{pH}$ variations can cause changes in the metabolic pathways of $\mathrm{HPB}$, which were due to changes in the composition of dominant species (Horiuchi et al., 2002). In the present study, 4 of the 10 most dominant phyla of hydA genes were correlated with $\mathrm{pH}$. Moreover, $\mathrm{pH}$ showed negative correlation with Eh in this study (Supplementary Figure 3), which also implied that Eh may play a certain role in affecting the HPB population structure. The fermentation reaction was really prevalent in the lower redox potential zone (Cammack and Robson, 2001; Jakobsen and Cold, 2007; Vignais and Billoud, 2007). So, it is reasonable that the observed HPB OTUs were negatively correlated with Eh in this study. Therefore, $\mathrm{pH}$ may directly or indirectly (i.e., by affecting one geochemical variable) affect the composition of HPB populations in the Tibetan hot springs.

Elevation reflected the difference between geographical and environmental factors. The elevations of the four geothermal areas in this study were different. Similarly, changes in environmental indicators caused by elevation, such as dissolved oxygen and hydrogen partial pressure, cannot be ignored either. Therefore, this result also suggests that, in addition to environmental factors, the influence of spatial variables on HPB community structure should also be considered.

\section{Spatial Variables Influencing HPB Population in the Tibetan Hot Springs}

The HPB populations in the studied Tibetan hot springs exhibited a spatial pattern, i.e., the HPB populations in the samples from the same area were more similar, implying that spatial variables affected HPB distribution among regions. Interestingly, the co-explanation of spatial variables and environmental factors reached 25\% (Figure 5). Among the studied Tibetan hot springs, spatial variables caused the difference in environmental conditions, which further jointly affected the HPB distribution. The $\mathrm{pH}$ of the Tibetan hot springs is generally neutral and alkaline. Only a few acidic hot springs were ever found in the DG area, while no acid hot spring was ever reported in the QZM area (Liu et al., 2019). Therefore, the DG area likely belonged to the magmatic systems and differed from those in the QZM area (Liu et al., 2019). In addition, among the studied hot spring samples, the $\mathrm{Cl}^{-} / \mathrm{SO}_{4}{ }^{2-}$ ratio in the DG area was 
TABLE 2 | Concentrations of major ions of the investigated hot springs in present study.

\begin{tabular}{|c|c|c|c|c|c|c|c|c|}
\hline \multirow[b]{2}{*}{ Samples } & \multicolumn{8}{|c|}{$\left(\mathrm{mg} \mathrm{L}^{-1}\right)$} \\
\hline & $\mathrm{Na}^{+}$ & $\mathbf{K}^{+}$ & $\mathrm{Ca}^{2+}$ & $\mathrm{Mg}^{2+}$ & $\mathbf{F}^{-}$ & $\mathrm{Cl}^{-}$ & $\mathrm{NO}_{3}{ }^{-}$ & $\mathrm{SO}_{4}{ }^{2-}$ \\
\hline QSYB09-3 & 381.83 & 28.72 & 0.13 & 0.90 & 11.63 & 139.71 & 0.53 & 67.72 \\
\hline QSYB09-4 & 394.37 & 28.18 & 0.42 & 0.55 & 11.83 & 142.27 & 0.13 & 60.25 \\
\hline MLJ05 & 719.92 & 82.95 & 7.16 & 1.35 & 1.73 & 618.46 & 0.00 & 17.08 \\
\hline DG01-3 & 315.37 & 25.05 & 0.97 & 0.05 & 26.89 & 185.17 & 2.25 & 87.17 \\
\hline DG01-4 & 308.07 & 26.08 & 1.21 & 0.23 & 26.84 & 185.82 & 1.93 & 87.95 \\
\hline DG01-5 & 297.56 & 27.15 & 0.86 & 0.12 & 27.33 & 187.38 & 1.59 & 88.44 \\
\hline DG01-6 & 312.53 & 25.84 & 2.02 & 0.13 & 27.81 & 191.31 & 1.85 & 90.18 \\
\hline DG02-2 & 303.05 & 24.78 & 0.99 & 0.16 & 27.05 & 186.08 & 1.67 & 88.28 \\
\hline QZM04 & 166.81 & 22.26 & 171.29 & 28.26 & 2.60 & 286.06 & 0.03 & 491.20 \\
\hline QZM04-1 & 167.04 & 20.70 & 170.30 & 26.45 & 2.68 & 291.13 & 0.03 & 499.79 \\
\hline QZM04-2 & 169.02 & 21.78 & 172.99 & 28.58 & 2.67 & 295.98 & 0.00 & 512.65 \\
\hline QZM04-3 & 172.20 & 23.14 & 169.89 & 28.11 & 2.52 & 272.29 & 0.00 & 472.11 \\
\hline QZM04-4 & 167.00 & 23.24 & 163.71 & 28.72 & 2.70 & 293.60 & 0.35 & 513.69 \\
\hline
\end{tabular}

higher than that in the QZM area (Table 2), which suggested that the hot springs in the DG area were more affected by liquid phase input, while the QZM area was more affected by gas phase input (Amenabar and Boyd, 2019). Furthermore, it is well known that most chemical components in geothermal water are primarily derived from its interactions with host reservoir rocks. The lithology of the reservoir host rocks in the DG area is basically granite, while the QZM area consists of marine carbonate minerals. Such lithology difference makes the hydrochemical type in the DG and QZM belong to $\mathrm{Na}-\mathrm{HCO}_{3}$ $\mathrm{Cl}$ and $\mathrm{Ca}-\mathrm{Na}-\mathrm{SO}_{4}-\mathrm{Cl}$, respectively (Guo et al., 2014, 2019; Liu et al., 2019; Li et al., 2020). Therefore, it is reasonable that the geological processes affect both environmental difference and the observed spatial variables causing the HPB differences in the studied Tibetan hot springs.

\section{hydA Gene Served as a Biomarker for Hydrogen Production Bacteria Exploration}

The functional genes were often used to explore the distribution and diversity of microbial functional groups (Yang et al., 2013; Jiang et al., 2014; Wu et al., 2015). In the present study, the hot spring sediments with positive PCR amplification of hydA genes were selected for the HPB isolation. Pure HPB culture was successfully obtained from the corresponding sediment samples, and the resulting pure HPB culture was successfully amplified for the hydA gene, followed by verifications for the function of hydrogen production and by the phylogenetic identification consistency between the resulting pure HPB culture and the 16S rRNA gene sequences from the same sediment samples. These results provided a new way of isolation and purification of functional microorganisms from environments.

In summary, the Tibetan hot springs host unique HPB populations, the hydA genes affiliated with Bacteroidetes and Spirobacteria dominated the studied samples, but that affiliated with Proteobacteria was lacking. The HPB community structure was correlated with $\mathrm{pH}$, temperature, elevation, and redox potential in the studied Tibetan hot springs. In addition, HPB strain QZM-1 was successfully isolated from the hot spring sediments in Quzhuomu area, and its hydA gene and function of hydrogen production were confirmed. These results are important for us to understand the distribution and function of HPB in hot springs.

\section{DATA AVAILABILITY STATEMENT}

The datasets presented in this study can be found in online repositories. The names of the repository/repositories and accession number(s) can be found in the article/ Supplementary Material.

\section{AUTHOR CONTRIBUTIONS}

GW and HJ conceived the study. LM, JY, DP, and GW performed on-site measurements and collected the samples. LM, JY, DP, W-JL, and GW analyzed geochemistry and microbiology of the samples. LM, LH and JY analyzed the sequencing data. LM, GW, and $\mathrm{HJ}$ drafted the manuscript. All authors reviewed results and commented on the manuscript.

\section{FUNDING}

This research was supported by grants from the National Natural Science Foundation of China (Grant Nos. 91951205, 41877322, and 41521001), the 111 Program (State Administration of Foreign Experts Affairs and the Ministry of Education of China, Grant No. B18049), Fundamental Research Funds for the Central Universities, China University of Geosciences (Wuhan), and State Key Laboratory of Biogeology and Environmental Geology, CUG (Grant No. GBL11805). 


\section{ACKNOWLEDGMENTS}

We are grateful to the editor and three reviewers for their positive and constructive comments and suggestions that significantly improved the manuscript.

\section{REFERENCES}

Amenabar, M. J., and Boyd, E. S. (2019). A review of the mechanisms of mineral-based metabolism in early Earth analog rock-hosted hydrothermal ecosystems. World J. Microbiol. Biotechnol. 35:29. doi: 10.1007/s11274-0192604-2

Avilan, L., Roumezi, B., Risoul, V., Bernard, C. S., Kpebe, A., Belhadjhassine, M., et al. (2018). Phototrophic hydrogen production from a clostridial FeFe hydrogenase expressed in the heterocysts of the cyanobacterium Nostoc PCC 7120. Appl. Microbiol. Biotechnol. 102, 5775-5783. doi: 10.1007/s00253-0188989-2

Baba, R., Kimura, M., Asakawa, S., and Watanabe, T. (2014). Analysis of FeFe -hydrogenase genes for the elucidation of a hydrogen-producing bacterial community in paddy field soil. FEMS Microbiol. Lett. 350, 249-256. doi: 10. 1111/1574-6968.12335

Baghchehsaraee, B., Nakhla, G., Karamanev, D., Margaritis, A., and Reid, G. (2008). The effect of heat pretreatment temperature on fermentative hydrogen production using mixed cultures. Int. J. Hydrogen Energy 33, 4064-4073. doi: 10.1016/j.ijhydene.2008.05.069

Bhandari, V., and Gupta, R. S. (2014). Molecular signatures for the phylum (class) Thermotogae and a proposal for its division into three orders (Thermotogales, Kosmotogales ord. nov and Petrotogales ord. nov.) containing four families (Thermotogaceae, Fervidobacteriaceae fam. nov., Kosmotogaceae fam. nov and Petrotogaceae fam. nov.) and a new genus Pseudothermotoga gen. nov with five new combinations. Antonie Van Leeuwenhoek 105, 143-168. doi: 10.1007/ s10482-013-0062-7

Boyd, E. S., Hamilton, T. L., Spear, J. R., Lavin, M., and Peters, J. W. (2010). FeFe -hydrogenase in Yellowstone National Park: evidence for dispersal limitation and phylogenetic niche conservatism. ISME J. 4, 1485-1495. doi: 10.1038/ismej. 2010.76

Boyd, E. S., Hamilton, T. L., Swanson, K. D., Howells, A. E., Baxter, B. K., Meuser J. E., et al. (2014). FeFe -Hydrogenase abundance and diversity along a vertical redox gradient in Great Salt Lake, USA. Int. J. Mol. Sci. 15, 21947-21966. doi: $10.3390 /$ ijms 151221947

Boyd, E. S., Spear, J. R., and Peters, J. W. (2009). FeFe hydrogenase genetic diversity provides insight into molecular adaptation in a saline microbial mat community. Appl. Environ. Microbiol. 75, 4620-4623. doi: 10.1128/aem. 00582-09

Brazelton, W. J., Nelson, B., and Schrenk, M. O. (2011). Metagenomic evidence for $\mathrm{H} 2$ oxidation and $\mathrm{H} 2$ production by serpentinite-hosted subsurface microbial communities. Front. Microbiol. 2:268. doi: 10.3389/fmicb.2011. 00268

Cammack, R., and Robson, R. L. (2001). Hydrogen as a fuel: learning from nature. Int. J. Hydr. Ener. 39, 15215-15223.

Caporaso, J. G., Lauber, C. L., Walters, W. A., Berg-Lyons, D., Huntley, J., Fierer, N., et al. (2012). Ultra-high-throughput microbial community analysis on the Illumina HiSeq and MiSeq platforms. ISME J. 6, 1621-1624. doi: 10.1038/ismej. 2012.8

Defeng, X., Nanqi, R., and Rittmann, B. E. (2008). Genetic diversity of hydrogenproducing bacteria in an acidophilic ethanol- $\mathrm{H}_{2}$-coproducing system, analyzed using the [Fe]-hydrogenase gene. Appl. Environ. Microbiol. 74:1232. doi: 10. 1128/AEM.01946-07

Edgar, R. C., Haas, B. J., Clemente, J. C., Quince, C., and Knight, R. (2011). UCHIME improves sensitivity and speed of chimera detection. Bioinformatics 27, 2194-2200. doi: 10.1093/bioinformatics/btr381

Fedonkin, M. A. (2009). Eukaryotization of the early biosphere: a biogeochemical aspect. Geochem. Int. 47, 1265-1333. doi: 10.1134/S0016702909130011

Frank, J. A., Reich, C. I., Sharma, S., Weisbaum, J. S., Wilson, B. A., and Olsen, G. J. (2008). Critical evaluation of two primers commonly used for amplification

\section{SUPPLEMENTARY MATERIAL}

The Supplementary Material for this article can be found online at: https://www.frontiersin.org/articles/10.3389/fmicb. 2021.569020/full\#supplementary-material

of bacterial 16S rRNA genes. Appl. Environ. Microbiol. 74, 2461-2470. doi: 10.1128/aem.02272-07

Ghimire, A., Frunzo, L., Pirozzi, F., Trably, E., Escudie, R., Lens, P. N. L., et al. (2015). A review on dark fermentative biohydrogen production from organic biomass: process parameters and use of by-products. Appl. Energy 144, 73-95. doi: 10.1016/j.apenergy.2015.01.045

Greening, C., Biswas, A., Carere, C. R., Jackson, C. J., Taylor, M. C., Stott, M. B., et al. (2016). Genomic and metagenomic surveys of hydrogenase distribution indicate $\mathrm{H}_{2}$ is a widely utilised energy source for microbial growth and survival. ISME J. 10, 761-777. doi: 10.1038/ismej.2015.153

Gregory, S. P., Barnett, M. J., Field, L. P., and Milodowski, A. E. (2019). Subsurface microbial hydrogen cycling: natural occurrence and implications for industry. Microorganisms 7:53. doi: 10.3390/microorganisms7020053

Guo, L., Wang, G. C., Sheng, Y. Z., Sun, X. Y., Shi, Z. M., Xu, Q. Y., et al. (2020). Temperature governs the distribution of hot spring microbial community in three hydrothermal fields, Eastern Tibetan Plateau Geothermal Belt, Western China. Sci. Total Environ. 720:13. doi: 10.1016/j.scitotenv.2020.13 7574

Guo, Q. H., Nordstrom, D. K., and McCleskey, R. B. (2014). Towards understanding the puzzling lack of acid geothermal springs in Tibet (China): insight from a comparison with Yellowstone (USA) and some active volcanic hydrothermal systems. J. Volcanol. Geothermal Res. 288, 94-104. doi: 10.1016/j. jvolgeores.2014.10.005

Guo, Q. H., Planer-Friedrich, B., Liu, M. L., Yan, K., and Wu, G. (2019). Magmatic fluid input explaining the geochemical anomaly of very high arsenic in some southern Tibetan geothermal waters. Chem. Geol. 513, 32-43. doi: 10.1016/j. chemgeo.2019.03.008

Guo, X. M., Trably, E., Latrille, E., Carrere, H., and Steyer, J. P. (2010). Hydrogen production from agricultural waste by dark fermentation: a review. Int. J. Hydrogen Energy 35, 10660-10673. doi: 10.1016/j.ijhydene.2010. 03.008

Holdeman, L., Cato, E. P., and Moore, W. E. C. (1977). Anaerobe Laboratory Manual. Blacksburg, VA: Anaerobe Laboratory, Virginia Polytechnic Institute and State University.

Horiuchi, J. I., Shimizu, T., Tada, K., Kanno, T., and Kobayashi, M. (2002). Selective production of organic acids in anaerobic acid reactor by $\mathrm{pH}$ control. Bioresource Technol. 82, 209-213. doi: 10.1016/s0960-8524(01) 00195-X

Huang, Q. Y., Dong, C. Z., Dong, R. M., Jiang, H. C., Wang, S., Wang, G. H., et al. (2011). Archaeal and bacterial diversity in hot springs on the Tibetan Plateau, China. Extremophiles 15, 549-563. doi: 10.1007/s00792-011-0386-z

Hungate, R. E. (1969). Chapter IV A Roll Tube Method for Cultivation of Strict Anaerobes. Amsterdam: Elsevier Ltd.

Iino, T., Mori, K., Uchino, Y., Nakagawa, T., Harayama, S., and Suzuki, K. (2010). Ignavibacterium album gen. nov., sp nov., a moderately thermophilic anaerobic bacterium isolated from microbial mats at a terrestrial hot spring and proposal of Ignavibacteria classis nov., for a novel lineage at the periphery of green sulfur bacteria. Int. J. Syst. Evol. Microbiol. 60, 1376-1382. doi: 10.1099/ijs.0. 012484-0

Jakobsen, R., and Cold, L. (2007). Geochemistry at the sulfate reductionmethanogenesis transition zone in an anoxic aquiferâĂŞA partial equilibrium interpretation using 2D reactive transport modeling. Geochim. Cosmochim. Acta 71, 1949-1966. doi: 10.1016/j.gca.2007.01.013

Jiang, H., Huang, L., Deng, Y., Wang, S., Zhou, Y., Liu, L., et al. (2014). Latitudinal distribution of ammonia-oxidizing bacteria and archaea in the agricultural soils of eastern China. Appl. Environ. Microbiol. 80, 5593-5602. doi: 10.1128/aem. 01617-14

Kasting, J. F. (1993). Earth's early atmosphere. Science 259, 920-926. doi: 10.1126/ science. 11536547 
Konhauser, K. O., Jones, B., Reysenbach, A. L., and Renaut, R. W. (2003). Hot spring sinters: keys to understanding Earth's earliest life forms. Can. J. Earth Sci. 40, 1713-1724. doi: 10.1139/e03-059

Lau, C. Yi, Jing, H., Jonathan, C., and Stephen, B. (2006). Highly diverse community structure in a remote central Tibetan geothermal spring does not display monotonic variation to thermal stress. FEMS Microbiol. Ecol. 57, 80-91. doi: 10.1111/j.1574-6941.2006.00104.X

Lau, M. C. Y., Aitchison, J. C., and Pointing, S. B. (2009). Bacterial community composition in thermophilic microbial mats from five hot springs in central Tibet. Extremophiles 13, 139-149. doi: 10.1007/s00792-0080205-3

Lau, M. C. Y., and Pointing, S. B. (2009). Vertical partitioning and expression of primary metabolic genes in a thermophilic microbial mat. Extremophiles 13, 533-540. doi: 10.1007/s00792-009-0240-8

Lepot, K. (2020). Signatures of early microbial life from the Archean (4 to $2.5 \mathrm{Ga}$ ) eon. Earth-Sci. Rev. 209:103296. doi: 10.1016/j.earscirev.2020. 103296

Li, R., Wu, G., Jones, B., and Shi, T. H. (2020). Microbial fabrics of geyserites around hot spring pools in Daggyai, Tibet, China. Terra Nova 32, 355-368. doi: $10.1111 /$ ter. 12465

Lindsay, M. R., Amenabar, M. J., Fecteau, K. M., Debes, R. V., Martins, M. C. F., Fristad, K. E., et al. (2018). Subsurface processes influence oxidant availability and chemoautotrophic hydrogen metabolism in Yellowstone hot springs. Geobiology 16, 674-692. doi: 10.1111/gbi.12308

Lindsay, M. R., Colman, D. R., Amenabar, M. J., Fristad, K. E., Fecteau, K. M., Debes, R. V., et al. (2019). Probing the geological source and biological fate of hydrogen in Yellowstone hot springs. Environ. Microbiol. 21, 3816-3830. doi: 10.1111/1462-2920.14730

Liu, J. F., Mbadinga, S. M., Ke, W. J., Gu, J. D., and Mu, B. Z. (2016). The diversity of hydrogen-producing microorganisms in a high temperature oil reservoir and its potential role in promoting the in situ bioprocess. Appl. Environ. Biotechnol. 1, 25-34. doi: 10.18063/AEB.2016.02.005

Liu, M. L., Guo, Q. H., Wu, G., Guo, W., She, W. Y., and Yan, W. D. (2019). Boron geochemistry of the geothermal waters from two typical hydrothermal systems in Southern Tibet (China): daggyai and Quzhuomu. Geothermics 82, 190-202. doi: 10.1016/j.geothermics.2019.06.009

Lubitz, W., Ogata, H., Rudiger, O., and Reijerse, E. (2014). Hydrogenases. Chem. Rev. 114, 4081-4148. doi: 10.1021/cr4005814

Ma, L., She, W., Wu, G., Yang, J., Phurbu, D., and Jiang, H. (2021). Influence of temperature and sulfate concentration on the sulfate/sulfite reduction prokaryotic communities in the tibetan hot springs. Microorganisms 9:583. doi: 10.3390/microorganisms 9030583

Magoc, T., and Salzberg, S. L. (2011). FLASH: fast length adjustment of short reads to improve genome assemblies. Bioinformatics 27, 2957-2963. doi: 10.1093/ bioinformatics/btr507

Mei, N., Zergane, N., Postec, A., Erauso, G., Ollier, A., Payri, C., et al. (2014). Fermentative hydrogen production by a new alkaliphilic Clostridium sp. (strain $\mathrm{PROH} 2$ ) isolated from a shallow submarine hydrothermal chimney in Prony Bay, New Caledonia. Int. J. Hydrogen Energy 39, 19465-19473. doi: 10.1016/j. ijhydene.2014.09.111

Pearson, A., Pi, Y. D., Zhao, W. D., Li, W. J., Li, Y. L., Inskeep, W., et al. (2008). Factors controlling the distribution of archaeal tetraethers in terrestrial hot springs. Appl. Environ. Microbiol. 74, 3523-3532. doi: 10.1128/aem. 02450-07

Peters, J. W., Schut, G. J., Boyd, E. S., Mulder, D. W., Shepard, E. M., Broderick, J. B., et al. (2015). FeFe - and NiFe -hydrogenase diversity, mechanism, and maturation. Biochim. Biophys. Acta-Mol. Cell Res. 1853, 1350-1369. doi: 10. 1016/j.bbamcr.2014.11.021

Sahl, J. W., Gary, M. O., Harris, J. K., and Spear, J. R. (2011). A comparative molecular analysis of water-filled limestone sinkholes in north-eastern Mexico. Environ. Microbiol. 13, 226-240. doi: 10.1111/j.1462-2920.2010.02324.x

Saitou, N., and Nei, M. (1987). The neighbor-joining method: a new method for reconstructing phylogenetic trees. Mol. Biol. Evol. 4, 406-425.

Schilter, D., Camara, J. M., Huynh, M. T., Hammes-Schiffer, S., and Rauchfuss, T. B. (2016). Hydrogenase enzymes and their synthetic models: the role of metal hydrides. Chem. Rev. 116, 8693-8749. doi: 10.1021/acs.chemrev. $6 \mathrm{~b} 00180$
Schmidt, O., Drake, H. L., and Horn, M. A. (2010). Hitherto unknown Fe-Fe -Hydrogenase gene diversity in anaerobes and anoxic enrichments from a moderately acidic fen. Appl. Environ. Microbiol. 76, 2027-2031. doi: 10.1128/ aem.02895-09

Schuchmann, K., Chowdhury, N. P., and Muller, V. (2018). Complex multimeric FeFe hydrogenases: biochemistry, physiology and new opportunities for the hydrogen economy. Front. Microbiol. 9:2911. doi: 10.3389/fmicb.2018. 02911

Schwartz, E., and Friedrich, B. (2006). “The $\mathrm{H}_{2}$-metabolizing prokaryotes," in The Prokaryotes: Volume 2: Ecophysiology and Biochemistry, eds M. Dworkin, S. Falkow, E. Rosenberg, K.-H. Schleifer, and E. Stackebrandt (New York, NY: Springer New York), 496-563.

Skirnisdottir, S., Hreggvidsson, G. O., Hjorleifsdottir, S., Marteinsson, V. T., Petursdottir, S. K., Holst, O., et al. (2000). Influence of sulfide and temperature on species composition and community structure of hot spring microbial mats. Appl. Environ. Microbiol. 66, 2835-2841. doi: 10.1128/aem.66.7.28352841.2000

Smetannikov, A. F. (2011). Hydrogen generation during the radiolysis of crystallization water in carnallite and possible consequences of this process. Geochem. Int. 49, 916-924. doi: 10.1134/S0016702911070081

Song, Z. Q., Wang, F. P., Zhi, X. Y., Chen, J. Q., Zhou, E. M., Liang, F., et al. (2013). Bacterial and archaeal diversities in Yunnan and Tibetan hot springs, China. Environ. Microbiol. 15, 1160-1175. doi: 10.1111/1462-2920. 12025

Spear, J. R., Walker, J. J., McCollom, T. M., and Pace, N. R. (2005). Hydrogen and bioenergetics in the Yellowstone geothermal ecosystem. Proc. Natl. Acad. Sci. U.S.A. 102, 2555-2560. doi: 10.1073/pnas.0409574102

Tamaki, H., Wright, C. L., Li, X. Z., Lin, Q. Y., Hwang, C. C., Wang, S. P., et al. (2011). Analysis of 16S rRNA amplicon sequencing options on the Roche/454 next-generation titanium sequencing platform. PLoS One 6:e25263. doi: 10. 1371/journal.pone.0025263

Tard, C., and Pickett, C. J. (2009). Structural and functional analogues of the active sites of the Fe -, NiFe -, and FeFe -Hydrogenases. Chem. Rev. 109, 2245-2274. doi: $10.1021 / \mathrm{cr} 800542 \mathrm{q}$

Tomazetto, G., and Oliveira, V. M. (2013). Investigation of the FeFe-hydrogenase gene diversity combined with phylogenetic microbial community analysis of an anaerobic domestic sewage sludge. World J. Microbiol. Biotechnol. 29, $2003-$ 2014. doi: 10.1007/s11274-013-1363-8

Vignais, P. M., and Billoud, B. (2007). Occurrence, classification, and biological function of hydrogenases: an overview. Chem. Rev. 107, 4206-4272. doi: 10. 1021/cr050196r

Vignais, P. M., Billoud, B., and Meyer, J. (2001). Classification and phylogeny of hydrogenases. FEMS Microbiol. Rev. 25, 455-501. doi: 10.1111/j.1574-6976. 2001.tb00587.x

Wang, S., Hou, W., Dong, H., Jiang, H., Huang, L., Wu, G., et al. (2013). Control of temperature on microbial community structure in hot springs of the Tibetan Plateau. PLoS One 8:e62901. doi: 10.1371/journal.pone. 0062901

Wu, G., Jiang, H. C., Dong, H. L., Huang, Q. Y., Yang, J., Webb, L., et al. (2015). Distribution of arsenite- oxidizing bacteria and its correlation with temperature in hot springs of the Tibetan- Yunnan geothermal zone in Western China. Geomicrobiol. J. 32, 482-493. doi: 10.1080/01490451.2014.938206

Xu, S. Y., He, P. Q., Dewi, S. Z., Zhang, X. L., Ekowati, C., Liu, T. J., et al. (2013). Hydrogen-producing microflora and $\mathrm{Fe}-\mathrm{Fe}$ hydrogenase diversities in seaweed bed associated with marine hot springs of Kalianda, Indonesia. Curr. Microbiol. 66, 499-506. doi: 10.1007/s00284-013-0302-0

$\mathrm{Xu}$, Y., and Glansdorff, N. (2002). Was our ancestor a hyperthermophilic procaryote? Comparative Biochem. Physiol. a-Mol. Integr. Physiol. 133, 677-688. doi: 10.1016/s1095-6433(02)00197-6

Yang, J., Jiang, H. C., Dong, H. L., Wu, G., Hou, W. G., Zhao, W. Y., et al. (2013). Abundance and diversity of sulfur-oxidizing bacteria along a salinity gradient in four qinghai-tibetan Lakes, China. Geomicrobiol. J. 30, 851-860. doi: 10.1080/01490451.2013.790921

Yang, J., Zhou, E. M., Jiang, H. C., Li, W. J., Wu, G., Huang, L. Q., et al. (2015). Distribution and diversity of aerobic carbon monoxide-oxidizing bacteria in geothermal springs of China, the Philippines, and the United States. Geomicrobiol. J. 32, 903-913. doi: 10.1080/01490451.2015.1008605 
Zgonnik, V. (2020). The occurrence and geoscience of natural hydrogen: a comprehensive review. Earth-Sci. Rev. 203:103140. doi: 10.1016/j.earscirev. 2020.103140

Zhang, Y. M., Wu, G., Jiang, H. C., Yang, J., She, W. Y., Khan, I., et al. (2018). Abundant and rare microbial biospheres respond differently to environmental and spatial factors in tibetan hot springs. Front. Microbiol. 9:2026. doi: 10.3389/ fmicb.2018.02096

Zheng, H. S., Guo, W. Q., Yang, S. S., Feng, X. C., Du, J. S., Zhou, X. J., et al. (2014). Thermophilic hydrogen production from sludge pretreated by thermophilic bacteria: analysis of the advantages of microbial community and metabolism. Bioresource Technol. 172, 433-437. doi: 10.1016/j.biortech.2014.09.020
Conflict of Interest: The authors declare that the research was conducted in the absence of any commercial or financial relationships that could be construed as a potential conflict of interest.

Copyright $\odot 2021 \mathrm{Ma}$, Wu, Yang, Huang, Phurbu, Li and Jiang. This is an openaccess article distributed under the terms of the Creative Commons Attribution License (CC BY). The use, distribution or reproduction in other forums is permitted, provided the original author(s) and the copyright owner(s) are credited and that the original publication in this journal is cited, in accordance with accepted academic practice. No use, distribution or reproduction is permitted which does not comply with these terms. 